\title{
Implementing School-Based Management in Indonesia
}

Mark Heyward, Robert A. Cannon, and Sarjono

September 2011 


\section{About the Authors}

Mark Heyward, PhD, MEdStud, has worked in education in Indonesia since 1992. He is currently a field operations advisor for the United States Agency for International Development's (USAID's) Decentralized Basic Education 1 (DBE1) program, implemented by RTI International. He plans and designs interventions, coordinates project teams' work, and helps build the capacity of local stakeholders

Robert A. Cannon, MA, MEdAdmin, has consulted on education and development in Indonesia since 1987 with the University of Indonesia, the World Bank, USAID, the Asian Development Bank, UNICEF, and the Australian Agency for International Development (AusAID). He has taught at the University of Indonesia and at the University of Adelaide, where he was associate professor and director of the Advisory Centre for University Education.

Sarjono, PhD, MSc, became DBE1's lead monitoring and evaluation (M\&E) specialist in early 2005. He developed and oversaw structured M\&E activities such as collecting data, measuring project impact, examining performance, and suggesting improvements in implementation.
This publication is part of the RTI Research Report series. Occasional Papers are scholarly essays on policy, methods, or other topics relevant to RTI areas of research or technical focus.

RTI International

3040 Cornwallis Road

PO Box 12194

Research Triangle Park, NC

27709-2194 USA

Tel: $\quad+1.919 .541 .6000$

Fax: $\quad+1.919 .541 .5985$

E-mail:_rtipress@rti.org

Web site: www.rti.org
RTI Press publication OP-0006-1109

This PDF document was made available from www.rti.org as a public service of RTI International. More information about RTI Press can be found at http://www.rti.org/rtipress.

RTI International is an independent, nonprofit research organization dedicated to improving the human condition by turning knowledge into practice. The RTI Press mission is to disseminate information about RTI research, analytic tools, and technical expertise to a national and international audience. RTI Press publications are peer-reviewed by at least two independent substantive experts and one or more Press editors.

\section{Suggested Citation}

Heyward, M., Cannon, R.A., \& Sarjono. (2011). Implementing school-based management in Indonesia. RTI Press publication No. OP-0006-1109. Research Triangle Park, NC: RTI Press. Retrieved [date] from http://www.rti.org/rtipress.
C2011 Research Triangle Institute. RTI International is a trade name of Research Triangle Institute.

All rights reserved. Please note that this document is copyrighted and credit must be provided to the authors and source of the document when you quote from it. You must not sell the document or make a profit from reproducing it.

Certain information in this paper is abstracted from a Decentralized Basic Education 1 study (RTI International, 2010). The full study report is available from the United States Agency for International Development's (USAID's) Development Experience Clearinghouse and from the project website, http://www.dbe-usaid.org. No copyright is asserted in the study report or any parts that may be incorporated herein.

doi:10.3768/rtipress.2011.op.0006.1109

www.rti.org/rtipress 


\section{Implementing \\ School-Based Management in Indonesia}

\author{
Mark Heyward, Robert A. Cannon, and Sarjono
}

\section{Abstract}

Indonesia, the world's fourth most populous nation, has been decentralizing its education sector for the past decade. In this context, school-based management is essential for improving the quality of education. A mixed-method, multisite assessment of a project that aimed to improve the management and governance of basic education in Indonesia documented positive impact on school-based management in both public and private schools, including madrasah (Islamic schools). The following factors were associated with this impact: (1) the program was explicitly based on government policy; (2) technical assistance was provided rather than funding, and the program was manageable and affordable for local partners; (3) the project strengthened local systems and institutions, building commitment at both provincial and district levels; (4) the program was school based and involved members of the entire school community: principals, teachers, staff, parents, and community members; and (5) training was provided on-site in school clusters, was ongoing, and included mentoring in schools to support implementation (one-off training events rarely result in successful reform).
\end{abstract}

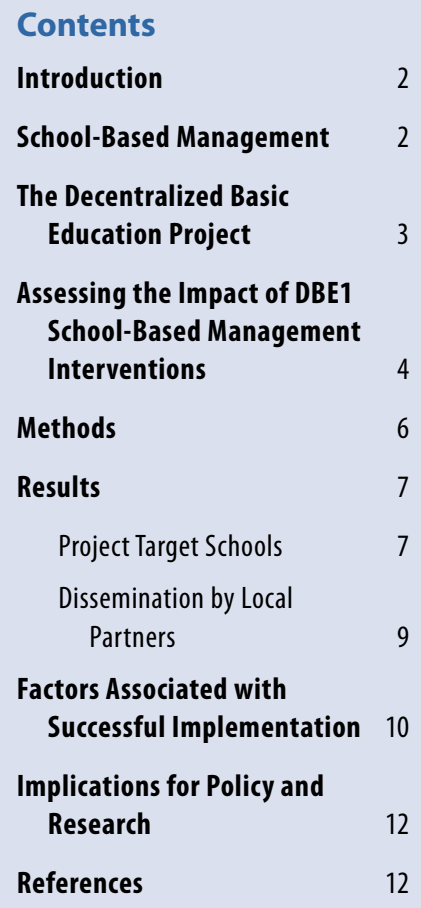




\section{Introduction}

School-based management is "the systematic decentralization to the school level of authority and responsibility to make decisions on significant matters related to school operations within a centrally determined framework of goals, policies, curriculum, standards, and accountability" (Caldwell, 2005, p. 1). The approach is also sometimes referred to as "selfmanaging schools," "site-based management," "school autonomy," or "local management."

There are at least two reasons for implementing school-based management: (1) it leads to better management and governance, and (2) it can create the enabling conditions for improved teaching and learning.

The government of Indonesia is transforming the education sector from a centralized system to one supporting school-based management. The experience of the Decentralized Basic Education 1 (DBE1) project demonstrates that school-based management can be implemented in Indonesian elementary schools and result in better management and governance. ${ }^{1}$ Although assessment of the direct learning benefits of school-based management was beyond the scope of this study, the study does show that strategic planning, improved financial management, and increased community participation can be achieved. This is intrinsically worthwhile, especially in the context of Indonesia, a country that is pursuing a broad program of democratization. Further, the factors associated with successful implementation of DBE1 are likely to be instructive for similar efforts in other countries undertaking decentralization of school management.

\section{School-Based Management}

School-based management has been implemented in many countries. Although evidence directly linking it with improved education quality or learning

1 Certain information in this paper is abstracted from a Decentralized Basic Education 1 study (RTI International, 2010). The full study report is available from the United States Agency for International Development's (USAID's) Development Experience Clearinghouse and from the project website, http://www.dbe-usaid.org. No copyright is asserted in the study report or any parts that may be incorporated herein. outcomes is scarce (Caldwell, 1998, 2005; Carnoy, Gove, Loeb, Marshall, \& Socias, 2008), international research suggests that school-based management can help create the enabling conditions for improvements in these areas (Ainley \& McKenzie, 2000; BarreraOsorio, Fasih, \& Patrinos, 2009; Caldwell, 2005; Crouch \& Winkler, 2008; Di Gropello, 2006; Fullan \& Watson, 2000; Umansky \& Vegas, 2007). A World Bank-led assessment of several impact evaluations of school-based management ${ }^{2}$ "found that schoolbased management changed the dynamics in the school because of changes in the behavior of parents (who became more involved) and teachers who changed their actions. These changes led to positive impacts on repetition rates, failure rates, and learning outcomes ..." (World Bank, 2010, pp. 1-2).

Improved leadership, administration, planning, and budgeting, along with transparency, accountability, and improved parental and community participation, create the conditions for improved and more relevant learning and teaching. The Indonesian experience suggests that combining programs designed to improve management and governance with programs designed to improve learning and teaching creates the proper conditions and the will for transformative change in schools (Bengoteko \& Heyward, 2007).

Recent research also suggests that over time, school-based management can improve learning outcomes (Barrera-Osorio et al., 2009; Borman, Hewes, Overman, \& Brown, 2003; Gertler, Patrinos, \& Rubio-Codina, 2007). The same is true for shortterm projects, "but only if very strongly coupled with exemplary pedagogics; that is, if one demonstrates how the improved management is used for improved pedagogy using pretty specific improved pedagogy" (L. Crouch, RTI, personal communication, January 4, 2010; emphasis in original). Analyses conducted in 2003 and 2006 of Program for International Student Assessment (PISA) test results showed that school autonomy in both budgeting and staffing were associated with improved learning outcomes. The results also suggested that students from both lower and higher socioeconomic backgrounds benefited

\footnotetext{
2 For a summary of this assessment, see World Bank, 2008a; a companion document is World Bank, 2008b.
} 
from increased choice, accountability, and school autonomy (Caldwell \& Harris, 2008).

Although the link between school-based management and improved learning outcomes has been established, this link is difficult to prove in the short term, especially in the absence of good testing instruments and procedures, as is the case in Indonesia (Cannon \& Arlianti, 2009). Notwithstanding this difficult-to-establish link, the purpose and value of school-based management extend beyond improving learning outcomes. Countries such as Indonesia pursue decentralization and localized school autonomy for many reasons, some of the most significant having to do with concerns about broad political and social development. School-based management provides opportunities for community development and learning about localized collective action (L. Crouch, RTI, personal communication, January 4, 2010). Moreover, effective and efficient school management is in itself a worthwhile goal. For these reasons, indicators of improved planning, transparency, and participation are important measures of impact (Di Gropello, 2006).

This study evaluates the effectiveness of DBE1 schoolbased management tools and methods by assessing various aspects of project performance and impact of the interventions.

\section{The Decentralized Basic Education Project}

DBE1, funded by the United States Agency for International Development (USAID), was implemented in Indonesia by RTI International between 2005 and 2011. It capitalized on the fact that starting in the late 1990s, the government of Indonesia has progressively adopted a range of policies expanding schools' autonomy in the context of regional autonomy. DBE1 is significant for being among the first donor-funded projects to work in this field after the introduction of these policies. For example, before central per capita school funding was implemented in 2005, school planning lacked substance because the school budgets were so small as to be inconsequential. With the new policy, school budgets increased dramatically, heightening the importance of planning and the leadership and participation of the principal and the school committee ${ }^{3}$ in governance and financial management.

DBE1 worked with 50 districts and local stakeholders to improve basic education management and governance, covering about 10 percent of Indonesia's entire population of approximately 240 million. The project team and the partner districts jointly and purposively selected the participating schools, according to agreed-upon criteria. Primarily the aim was to select schools that demonstrated a strong interest in joining the program. Two clusters of 10 elementary schools were selected in each district, and at least one Islamic school (known as a madrasah) was included in each cluster. (The government elementary schools were already grouped into preexisting clusters within the Indonesian system.) Four junior secondary schools also were selected, making a total of 1,310 target schools across two cohorts. The cohorts were introduced into the project in two phases, one in 2006 and another in 2007, with about 500 schools in Cohort 1 and slightly fewer than 700 in Cohort 2.

At the same time, the project team selected a small group of nontarget elementary schools from neighboring subdistricts as a comparison group. ${ }^{4}$ The project staff measured these schools against key indicators at the baseline data collection point and at regular intervals throughout the project, to determine the extent to which the schools took up project interventions themselves that they had heard about through dissemination activities. ("Take up" in this instance means the adoption or adaptation of project interventions by other parties, plus implementation using nonproject funds.)

The project trained school supervisors (who are employed by local governments) to enable them to facilitate cluster-based training and provide in-school

3 School committees partner with the school principal and teachers to make decisions, contribute ideas, and offer advice as needed. Ideally, their members are selected by parents and the community. In Indonesia, school committees are also responsible for approving school development plans and budgets.

4 Note that this was not a control group. No attempt was made to quarantine the schools from the effects of the project, as one objective was to determine the extent to which the project had an impact on these schools even though they received no direct assistance. 
mentoring. DBE1 worked with these facilitators in assisting schools with preparing and implementing 4-year school development plans. These plans (1) focused on quality improvement, (2) were based on needs identified through data collected and analyzed in a school profile, (3) reflected stakeholders' priorities and aspirations, (4) covered all main components of the school program, (5) drew upon multiple resources, (6) linked directly to school annual work plans and budgets, and (7) could be effectively implemented and monitored by the school committees and other stakeholders. For most schools, this approach of basing the planning process on data collection and analysis was entirely new.

Each school designated a working group (including the principal, a teacher, and representatives of the community and the school committee) to prepare the plans. The project facilitators administered a series of training activities to the working groups at the cluster level, followed by in-school mentoring. The project also developed and introduced a school database system to assist the working groups with the data collection and analysis that would form the basis for the school plans. This system was not immediately usable to those schools (especially rural ones) that did not have a computer, but the Ministry of National Education has planned for every school to have a computer by 2012 .

Over a 3-year period, the project provided each school with approximately 23 days of training and 23 mentoring visits (limited to the 24 selected schools in each district). The training focused on principals and local education leaders to improve their leadership skills and encourage a more open, transparent, and participatory approach to school leadership. Much of the training also went toward establishing the role of school committees in the planning process and other areas.

The logic of the project's approach was as follows. By purposively selecting a group of schools thought to have the motivation and capacity for change and by providing these schools with an intensive program of support, DBE1 would create a core group of successful schools that could model the desired change. At the same time, the project developed the capacity of a group of district facilitators who could disseminate the program to a wider group of schools, with the districts' support, using tools developed by the project and piloted in the target schools. This approach differs from the more common, topdown "cascade" approach. Instead it is a lateral or "sideways" approach to dissemination. Key elements of the approach in the Indonesian context were (1) to base all interventions firmly and explicitly on current government policy and (2) to work within the existing school cluster system using the government school supervisors as facilitators.

\section{Assessing the Impact of DBE1 School-Based Management Interventions}

Impact is generally defined as a change in a development outcome that is attributable to a defined program intervention (Gertler, Martinez, Premand, Rawlings, \& Vermeersch, 2011; USAID, 2011; White, 2009). For the purposes of this study, impact is defined as changes attributable to the DBE1 program of interventions. To determine impact, the "counterfactual" value must be determined (i.e., what the schools would have been like without DBE1 interventions).

In theory, the counterfactual value would be determined by establishing a control group that did not receive the interventions. However, in the world of educational development, this option often is neither realistic nor practical. Establishing a control group would require (1) identifying a group of schools sufficiently similar on a range of variables, which typically would mean schools that were geographically close; and (2) quarantining this group from any influence or "contamination" from the project's activities. This second requirement would have run counter to the aims of the project, which encouraged dissemination of outcomes as widely as possible. (This issue is addressed in the Methods section below.)

Without a counterfactual value based on the controlgroup methodology, some other means is needed to account for the changes in school-based management 
set out in this paper. Important questions are: Were there other sources of development, enacted by government or other donors, that contributed to the outcome described here? Were schools already improving anyway as part of a national trend in response to government policies? Were any other forces for change operating in the DBE1 schools at inception?

We acknowledge that other projects may have had some influence at a general, district level, but it was weak and did not occur in the specific schools participating in DBE1. We can make this argument because DBE1 was working with schools that had received no other direct project support either before or concurrently with DBE1. It is known that the United Nations Children's Fund (UNICEF) Mainstreaming Good Practices in Basic Education (MGPBE) Project (see Mainstreaming Good Practices in Basic Education, 2009) was operating concurrently in one of the 50 DBE1 districts from 2007 to 2010, and that three DBE1 districts had participated for 1 year in the earlier USAID Managing Basic Education Project Phase 3 (MBE) from 2005 to 2006 (see RTI International, 2006). But whatever impact these other projects may have had in these districts, given the changes evidenced in schools following DBE1 interventions, it is unlikely that the impact of the earlier projects had transferred significantly to the selected DBE1 schools in those districts. Moreover, evidence from the 47 districts supported solely by DBE1 was likely to outweigh, by strength of numbers, that of the four districts influenced by these projects.

Were schools already improving anyway as part of a national trend in response to the government policies described below? Many schools had attempted to implement the spirit of the decree, but without much success. The baseline data for the three projects mentioned here-MBE, DBE1, and MGPBEillustrate this condition in schools (RTI International, 2006, 2010; Mainstreaming Good Practices in Basic Education, 2009).

To answer the question "Were any other forces for change operating in the DBE1 schools at inception?" we might conclude that schools felt a widespread need for assistance and change, as reflected in the very rapid take-up of school-based management ideas and strategies-but little actual change had occurred before the DBE1 interventions (discussed under Results below). Again, this conclusion from the DBE1 monitoring data from baseline is also reflected in the MGPBE and MBE baseline data.

The findings from all three projects that schools entered the interventions with very low scores on school management indicators suggests that nontarget schools likely were similar to those chosen for the projects and were not improving much, independent of project support. This finding is consistent over the different times of the projects' inception, and is also consistent in their widely geographically dispersed districts across Indonesia. These locations ranged from Aceh in the west, where DBE1 was working; to Maluku in the east, where MGPBE was providing support; to the more densely populated areas of Java and Sumatra, where all these projects worked.

Moreover, the school-felt need for change that was identified in these projects was considerably strengthened by changes in government policy in the early 2000s. In 2002, a new regulation mandated that all districts have school committees and education boards (Kepmendiknas No. 044/U/2002). With the passage of the Law on the National Education System in 2003 (No. 20/2003), Indonesia formally adopted a policy of school-based management for all of its public and private schools and madrasah. Following this, in 2005, the government issued a regulation clearly identifying the standards it expected for school-based management, including school development planning (Peraturan Pemerintah 19/2005). Implementation of all three policies remains a work in progress. Also in 2005, the government introduced School Operational Funding (Bantuan Operasional Sekolah, known as BOS). As a result, since then schools have received per capita grant funding from the government, giving them for the first time a reliable income stream and some financial independence. In 2009, BOS funding was increased by more than 50 percent. A further increase of 30 percent is planned for 2012 .

Based on the findings of our mixed-method, multisite study, we can state with reasonable confidence that a 
combination of felt need within schools, strengthened by supportive government regulations, created an impetus for change and for implementation of school-based management. What was lacking was the capacity to do so. DBE1 and other projects' interventions provided the support necessary to develop that capacity in schools. Schools learning about school-based management for the first time through dissemination programs late in the project showed low-level initial scores on indicators of schoolbased management, similar to those in target schools early in the project. As reported below in the Results section (and illustrated there in Figure 1), the take-up was rapid and sustained. This change also held among even the late-arriving dissemination schools. The study found that this was in part a result of the motivational factors described above.

By way of conclusion, we present the argument that the DBE1 data, combined with the experience of two other similar basic education projects working in different geographical locations and at different times, support the reasonable assertion that DBE1 did have an impact of the magnitude presented in this paper. The counterfactual value constructed here is that without the DBE1 interventions, schools would have continued to operate with characteristics very similar what we found at baseline.

\section{Methods}

This study assessed the effectiveness and impact of DBE1 school-based management interventions in terms of (1) changes in management and governance in project target schools and communities, and (2) the extent to which the interventions were taken up and replicated beyond the scope of the project.

Baseline data were collected from all target schools prior to project interventions and regularly over 5 years to measure performance against the baseline. As noted earlier, in the absence of a control group, this baseline acts as the counterfactual value (i.e., if the project had no impact on practices, we assume that baseline values would persist throughout the life of the project). Although this approach provides good evidence of project performance, impact can never be proven as definitively as it can be in a controlled experiment; it is always possible that changes observed in schools are caused by factors other than the project interventions. However, by using a mixed-method approach to track change over time and triangulate the findings, we can demonstrate impact "beyond reasonable doubt." 5 The use of mixed-method research has emerged over the past 20 years as an alternative to both the quantitative and qualitative research traditions. This type of research uses whatever combination of methodological tools is necessary to answer research questions within implementation constraints (Teddlie \& Tashakkori, 2009).

The project team conducted a comprehensive series of studies between 2008 and 2010 to better assess the impact that DBE1 programs had on schools and to communicate a richer and more compelling overview of the program and its impacts on schools and communities. The result was, in fact, a comprehensive mixed-method study. The following are various data-gathering methods and instruments used to assess the impact of DBE1 school-based management interventions:

1. Routine project monitoring and analysis of achievement against baseline data on 10 (out of 22) performance indicators

2. A series of studies exploring the extent of implementation of school development plans in the approximately 500 target elementary schools in Cohort 1:

a. First, two annual quantitative surveys of all target schools, conducted in 2009 and 2010

b. Second, two qualitative field surveys, conducted to test the validity of the quantitative data (the project team carried out one in a sample of 32 schools, and national counterparts from the Ministry of National Education and the Ministry of Religious Affairs carried out another in a sample of 46 schools)

\footnotetext{
5 See Heyward, Cannon, and Sarjono (2011) for a more detailed explanation of the mixed-method approach for this study, including approaches to triangulation and to addressing potential researcher bias. The article describes the challenges in achieving a "gold standard" impact evaluation in the field. Also see Mayne (1999) for an account of this kind of "contribution analysis," which is also helpfully illustrated in a development project context by Kotvojs and Shrimpton (2007).
} 
3. Three studies of school funding, which investigated the following:

a. The level of community support for local schools over 3 years following commencement of DBE1 interventions

b. Outcomes of a program to help school committees obtain funding from village budgets through village development planning forums (musrenbangdes)

c. The impact of school unit-cost analysis on district and provincial funding for schools

4. An interview-based survey of the principals of all target schools on their perceptions of the project's impact in their schools

5. An in-depth, qualitative participant observation study conducted over a 1-month period in eight school clusters located in two provinces

6. A series of studies to document the extent and quality of DBE1 school-based management programs replicated in nontarget schools with funding from local government and other agencies, as follows:

a. Documentation of the extent of dissemination; specifically, the number of schools replicating DBE1 programs and amount and sources of counterpart budgets spent (the evaluation team gathered data by reviewing counterpart budgets and funding records, and verified the collected information through field visits)

b. Qualitative field surveys in a sample of 92 schools conducted by project teams in 2008 , followed by a second assessment in the same schools in 2010 to determine sustainability and impact of the disseminated interventions

c. Monitoring of the extent, nature, and quality of dissemination of DBE1 school-based management programs in 105 nontarget schools located near target schools, over the 5 years of the project

7. An independent midterm review of DBE1 (The Mitchell Group, 2008) to provide an additional reference point.

\section{Results}

The combined findings showed consistently that the DBE1 interventions had a positive impact on Indonesian schools in terms of improving planning, community participation, and transparency, and had an impact on the system as a whole through adoption of the interventions by others.

\section{Project Target Schools}

As illustrated in Figure 1, at the time of the baseline survey, only 2 percent of project schools in Cohort 1 had good-quality school development plans, as defined by a set of 32 agreed-upon criteria. After schools received DBE1 interventions, the figure rose to 96 percent. Field studies showed that among the 7,603 programs listed in these plans for the first year, 74 percent were implemented by schools and their communities. In the second year, 79 percent of plans were implemented. This resulted in targeted professional learning programs for teachers; improvements to the learning environments in many schools; and better teaching resources, such as the addition of computers, textbooks, and teaching aids. Although the study cannot demonstrate that implementation of these programs led to improved learning outcomes, we can reasonably conclude that it helped create the conditions for improved learning outcomes.

The fact that this many schools took up the new planning and programming techniques immediately following the first interventions suggests that the readiness for change was real and that the schools were indeed feeling a high level of need, as described above. During the period between the baseline and first measure, DBE1 provided intensive support to schools to facilitate the changes. An even more significant finding illustrated in Figure 1 is that the improvements were sustained and generally increased in subsequent measures, after this intensive project support had been withdrawn.

Figure 1 also shows improvements on indicators of transparency and community participation. Prior to DBE1, schools rarely disseminated their financial reports in more than two venues. At the baseline only 16 percent did so, with over 50 percent reporting to 
Figure 1. Performance against the baseline (Cohort 1: 526 schools)

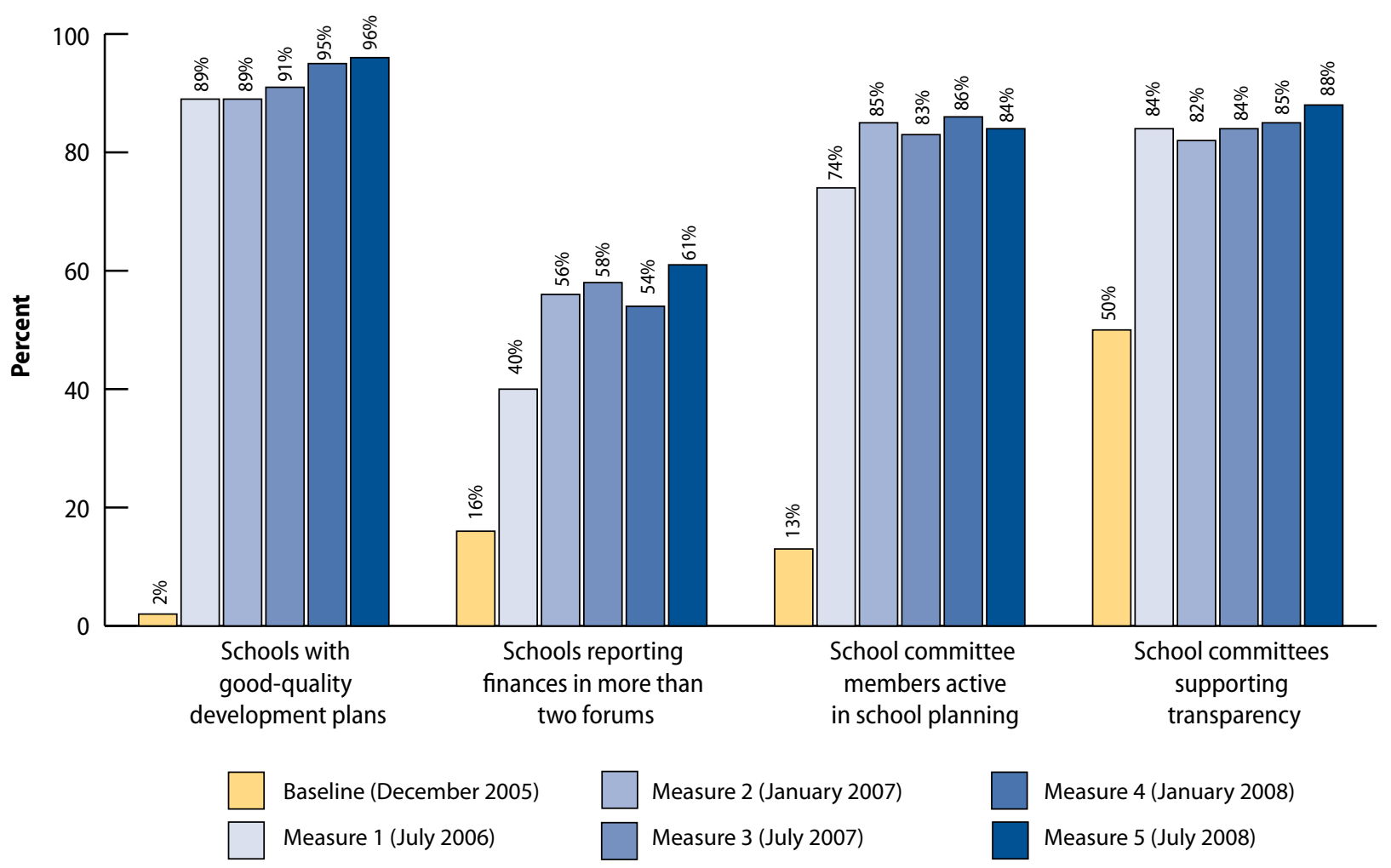

their communities in only one venue or not at all. By the time of the fifth measurement, 61 percent of schools were disseminating their financial reports in three or more forums. This included posting the reports on school notice boards and reporting at public events and annual parent meetings.

School committees were important in promoting this increase in school transparency. An increasing number of school committees requested that their school publish a financial report to the public, post it on the school notice board, or send it directly to the parents. The figure rose from 50 percent at baseline to 88 percent at the last measurement.

The role of school committees in school planning and budgeting also increased markedly. While only 13 percent of school committees participated in the planning and budgeting process at baseline, the figure rose to 84 percent after interventions. Local communities subsequently contributed over 25 billion rupiah, or Rp (approximately $\$ 2.6$ million) in either cash or noncash support for schools to implement their development plans. This is an average of $\$ 2,446$ contributed to each school-a significant sum for the mostly poor communities. This contribution was clearly a result of involving school communities in the preparation of school development plans, since no such contributions were forthcoming in communities that were not involved in early efforts by local governments to disseminate the program.

An additional Rp 1.1 billion $(\$ 120,000)$ was allocated from village budgets for school development programs in the 106 villages studied (about $\$ 1,132$ per village, or $\$ 283$ per school). This was a new source of funding for Indonesian schools. In addition, as a result of DBE1 school unit-cost analysis in 49 districts, allocations to schools from regional budgets increased by over Rp 1 trillion (over $\$ 100$ million). Again, the data are unable to reflect any changes or improvements in learning outcomes. However, enhanced community participation and increased funding can help create the necessary conditions for improved outcomes. 
Around 99 percent of principals in target schools reported that they believed DBE1 had had a positive impact on their school. Many gave detailed accounts and concrete examples of impact. The impact most frequently mentioned was on school planning, followed by management, leadership, and administration. The qualitative case studies found that DBE1 had "a strong, broad, and deep impact on schools, school committees, parents, teachers and students. The evidence found for transparent, participatory, and responsive management practices was especially strong" (RTI International, 2010). Although the impact of these changes in improving learning outcomes is unknown, DBE1 interventions did improve the management and governance of target schools.

\section{Dissemination by Local Partners}

The aim of the DBE1 project was to improve capacity and achieve significant school reforms that could be disseminated to other schools through independent funding. Given the investment in technical assistance in target schools, it would be disappointing indeed if there were no discernable impact. In this sense, the real test of the DBE1 approach to school-based management is the extent to which it was adopted by nontarget schools.

Dissemination, or take-up, of the project has been impressive. For every one target school in which the program was fully funded by DBE1, another 12 schools have now implemented aspects of the program with independent funding. As of March 2011, good practices developed under the project had been implemented in over 15,214 schools in 74 districts with funding from local governments, the Ministry of Religious Affairs, private foundations, and the schools themselves. This is in addition to the 1,310 target schools fully funded by the project. The most common focus of these programs was the DBE1 school development planning methodology (Figure 2).

No baseline assessment could be conducted for dissemination schools (because these were not identified until after they had implemented the DBE1 program). However, through reviewing documents from previous years or interviewing school personnel,
Figure 2. Types of DBE1 school-based management programs disseminated

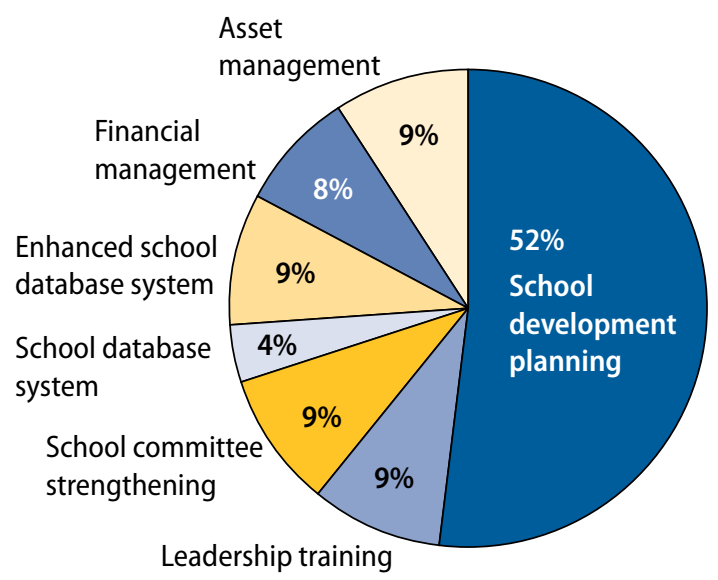

survey teams determined that few if any of the schools had previously prepared plans that met either government guidelines or DBE1 criteria. The DBE1 internal studies conducted in 2008 and 2010 found that most sampled dissemination schools prepared good-quality plans that complied with government standards. Furthermore, 70 percent of planned programs were being implemented, resulting in better school management and governance plus school improvement. Similar to what we found in target schools, some 90 percent of principals surveyed from the dissemination schools believed that the program had had a positive impact on their school and were able to give concrete examples of that impact.

The monitoring team found that the quality of dissemination programs, although varied, was satisfactory. Moreover, the quality of the implementation process and outcomes improved between 2008, when DBE1 staff conducted the first survey, and 2010, when they carried out the second two surveys. While school development planning remained the main focus of dissemination, as previously illustrated in Figure 2, more schools were implementing a greater variety of DBE1 schoolbased management programs, making the process more comprehensive. Additional schools received mentoring as follow-up to classroom-based training, and the participation of school committees also increased. 
In summary, the studies show that DBE1 schoolbased management interventions are improving school-based management in Indonesia and that the project's interventions can be implemented without further project support. Project interventions have resulted in better management and governance in schools where they have been implemented. Many principals are becoming more open, transparent, and participatory in their management approach, school committees are becoming more active, and schools have prepared and are implementing school development plans based on comprehensive data analysis and involvement of a range of stakeholders. In short, project interventions are instrumental in implementing school-based management in Indonesia.

Figure 3 highlights both the impressive level of takeup of DBE1 school-based management programs among districts and schools and the pronounced differences among provinces. Analysis of these differences revealed an interesting set of success factors, discussed in the following section.

\section{Factors Associated with Successful Implementation}

Stakeholders, implementers, and beneficiaries identified several factors as associated with the impacts described above. Their input, along with a comparison of results (1) between different regions, (2) between different groups of dissemination schools, (3) between dissemination schools and target schools where the project fully funded implementation, and (4) between target schools and neighboring schools selected at the start of the project, reveals the following set of factors associated with the successful implementation of project interventions.

The program was firmly and explicitly based on government policy. Indonesia's policy on schoolbased management is generally regarded as well founded (World Bank, 2004). The challenge for Indonesia is to implement the policy across its vast and diverse school system. DBE1 worked with national counterparts from the Ministry of National Education and the Ministry of Religious Affairs in

Figure 3. Number of schools disseminating DBE1 programs, by funding source, as of March 30, 2011

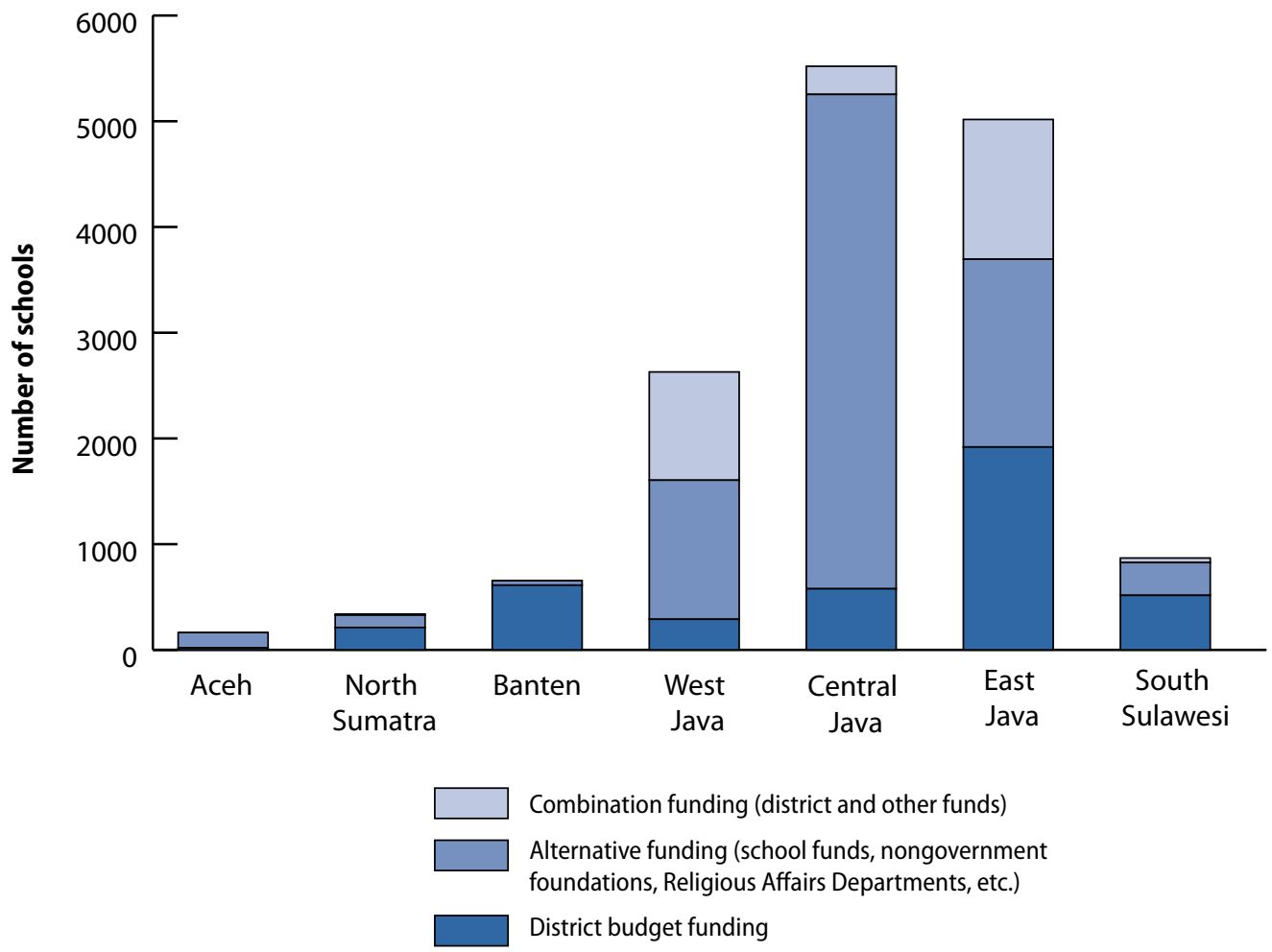


developing and piloting methodologies to support the implementation of these policies, and in some cases the project team revised and updated these methodologies in response to changes in national policy during the implementation period. In the view of key stakeholders, government counterparts, beneficiaries, and DBE1 personnel, one of the most crucial aspects of the project's approach was to consistently and explicitly align methodologies to the latest government regulations and policy at both the national and district levels (RTI International, $2007,2009)$. This approach provided the project with a mandate and enabled it to successfully translate established international good practice into the current Indonesian context. The explicit alignment of these methodologies with current regulations as well as with established good practice proved to be an important factor in the positive response of schools and the take-up by districts and related agencies.

\section{Technical assistance was provided rather than funding, and the program was manageable and} affordable for local partners. The study found that the methodologies for school development planning and other aspects of the school-based management program generally were within the financial reach of local governments and schools and could be implemented by local education authorities and other agencies. The cost of implementing DBE1's full school-based management program is around $\mathrm{Rp} 8.5$ million (\$900) per school. Working within the cluster system, a school can fund the complete DBE1 schoolbased management program, without reducing quality, over a period of 3 to 4 years at $\$ 200$ to $\$ 300$ per year. This is affordable within current school funding arrangements.

The project worked with and strengthened local systems and institutions, building commitment at both provincial and district levels. In cases where districts committed to the full implementation of school-based management programs (as opposed to just one component, typically school development planning), the impact was profound. In these districts, schools produced better-quality plans, support for implementation was stronger, and impact extended to greater numbers of schools.
When institutionalized through changes in government policy, as in the case of Boyolali District in Central Java, dissemination resulted in a broad impact across all schools in a district or province. In this particular district, following the success of initial interventions, the local government formalized a policy requiring all schools to adopt the DBE1 school planning and budgeting model and, beyond this, requiring district-level education development planning and budgeting to be based on the needs and priorities identified in the school plans. As a result, this program was disseminated to every school in the district and district planning is now far more responsive, bottom-up, and needs based than was previously the case.

Furthermore, as with other demand-driven development projects, DBE1 was a partnership. The two key partners-local governments and the project implementation team-shared responsibility for achieving agreed-upon objectives. Results, however, were not even across the target schools or across the dissemination schools, and comparisons in outcomes between regions suggest that both internal and external factors (and the interplay between the two) were associated with successful implementation. The most significant element in this dynamic seems to have been the level of commitment of the district or province and the capacity of the implementation team to leverage and build that commitment.

The program was school based and involved members of the entire school community: the principal, teachers, staff, parents, and community members. As described above, the percentage of target schools that actively involved community members in the preparation of development plans rose from 13 percent at baseline to over 80 percent after DBE1 interventions. The study of dissemination schools found that where the community was not involved, results could be disappointing. In 2008, no contributions were forthcoming from the community in the surveyed dissemination schools, in contrast to the prevalent community support achieved in the project target schools. The 2010 studies found that community participation was associated with improved rates of completion of school planning, better-quality plans, and improved rates of program implementation. 
Training was provided on-site in school clusters, was ongoing, and included mentoring in schools to support implementation (one-off training events rarely result in successful reform). Compared to those districts that followed the cluster model, districts that disseminated the program widely and did not use the cluster-based approach achieved disappointing results. The use of mass workshops to "socialize" a new policy or practice is common in Indonesia and a part of the bureaucratic culture; however, the study found that this approach did not result in concrete outcomes in schools. The aforementioned program in Boyolali District, for example, was conducted in clusters. All schools applied most of the DBE1 phases and demonstrated a 100 percent success rate in completing preparation of plans. In contrast, the schools in neighboring Klaten District conducted only one phase, socialization, and the success rate was nil.

\section{Implications for Policy and Research}

This mixed-method, multisite study demonstrated that school-based management can be successfully implemented in Indonesia to improve the management and governance of schools. Furthermore, the school-based management interventions developed, tested, and implemented through the USAID-funded DBE1 project significantly enhanced good practices.

There are many more lessons to learn, and longitudinal studies should be conducted to determine the long-term impacts of projects such as DBE1 in Indonesia and to identify factors associated with sustainability. There is a clear need for a stronger, independent body of research on which to base program design and to help ensure that development efforts are well directed.

Also, the findings of this study and the lessons of DBE1 are relevant to those involved in the international effort to support the Indonesian government and people to improve basic education for Indonesia's children. They are also relevant in the broader effort to develop basic education and improve the management and governance of schools worldwide. These lessons reinforce many research findings into school reform conducted in Indonesia and elsewhere (Barber \& Mourshed, 2007; Cannon \& Arlianti, 2008; Fullan 2001, 2007). This study adds to the body of research by identifying factors associated with successful implementation in the current Indonesian context.

\section{References}

Ainley, J., \& McKenzie, P. (2000). School governance: Research on educational and management issues. International Education Journal, 1(3), 139-151. Retrieved May 11, 2011, from http://iej.cjb.net

Barber, M., \& Mourshed, M. (2007). How the world's best performing school systems come out on top. London: McKinsey and Company.

Barrera-Osorio, F., Fasih, T., \& Patrinos, H. A. (with Santibáñez, L.). (2009). Decentralized decisionmaking in schools: The theory and evidence on school-based management. Washington, DC: World Bank. Retrieved September 6, 2011, from http://siteresources.worldbank.org/EDUCATION/ Resources/278200- 1099079877269/5476641099079934475/547667-1145313948551/ Decentralized_decision_making_schools.pdf
Bengoteko, B., \& Heyward, M. (2007, February 3). School-based management: Can it work in Indonesia? The Jakarta Post.

Borman, G. D., Hewes, G. M., Overman, L. T., \& Brown, S. (2003). Comprehensive school reform and achievement: A meta-analysis. Review of Educational Research, 73(2), 125-230.

Caldwell, B. J. (1998). Self-managing schools and improved learning outcomes: Report on autonomy and quality in school education. Canberra, Australia: Department of Employment, Education Training and Youth Affairs. 
Caldwell, B. J. (2005). School-based management. Education Policy Series, No. 3. Paris, France: The International Institute for Educational Planning (IIEP) and Brussels, Belgium: The International Academy of Education (IAE); United Nations Educational, Scientific and Cultural Organization (UNESCO). Retrieved September 6, 2011, from http://unesdoc.unesco. org/images/0014/001410/141025e.pdf

Caldwell, B. J., \& Harris, J. (2008). Why not the best schools? Camberwell, Victoria, Australia: ACER Press.

Cannon, R., \& Arlianti, R. (2008). Review of education development models: Lessons from models and strategies for increasing access to quality basic education in Indonesia. Final report prepared for the World Bank. Jakarta, Indonesia: World Bank.

Cannon, R. A., \& Arlianti, R. (2009). An exploratory study of the Ujian Nasional [National Endof-School Examination]. Prepared under the Decentralized Basic Education 3 (DBE3) project. Jakarta, Indonesia: United States Agency for International Development (USAID).

Carnoy, M., Gove, A. K., Loeb, S., Marshall, J. H., \& Socias, M. (2008). How schools and students respond to school improvement programs: The case of Brazil's PDE [Plano de Desenvolvimento de Escola]. Economics of Education Review, 27(1), 22-38.

Crouch, L., \& Winkler, D. (2008). Governance, management and financing of education for all: Basic frameworks and case studies. Background paper for the Education for All Global Monitoring Report 2009, Overcoming inequality: Why governance matters. Report No. 2009/ED/EFA/MRT/PI/04. Brussels, Belgium: UNESCO. Retrieved September 6, 2011, from http://unesdoc.unesco.org/ images/0017/001787/178719e.pdf
Di Gropello, E. (2006). A comparative analysis of school-based management in Central America. World Bank Working Paper No. 72. Washington DC: World Bank. Retrieved September 6, 2011, from http://siteresources.worldbank.org/ INTINDIA/4371432-1194542398355/21543243/

ComparativeAnalysisofSchoolBased ManagementinCentralAmerica.pdf

Fullan, M. (2001). Leading in a culture of change. San Francisco: Jossey-Bass.

Fullan, M. (2007). The new meaning of educational change (4th ed.). New York: Teachers College Press.

Fullan, M., \& Watson, N. (2000). School-based management: Reconceptualizing to improve learning outcomes. School Effectiveness and School Improvement, 11(4), 453-473.

Gertler, P. J., Martinez, S., Premand, P., Rawlings, L. B., \& Vermeersch, C. M. J. (2011). Impact evaluation in practice. Washington, DC: World Bank. Retrieved September 6, 2011, from http:// siteresources.worldbank.org/EXTHDOFFICE/ Resources/5485726-1295455628620/Impact_ Evaluation_in_Practice.pdf

Gertler, P., Patrinos, H. A., \& Rubio-Codina, M. (2007). Methodological issues in the evaluation of school-based management reforms. Doing Impact Evaluation Series, No. 10. Washington, DC: World Bank. Retrieved September 6, 2011, from http://siteresources.worldbank.org/INTISPMA/ Resources/383704-1146752240884/Doing_ie_ series_10.pdf

Heyward, M., Cannon, R. C., \& Sarjono. (2011). Implementing school-based management in Indonesia: Impact and lessons learned. Journal of Development Effectiveness, 3(3): 371-388.

Kotvojs, F., \& Shrimpton, B. (2007). Contribution analysis: A new approach to evaluation in international development. Evaluation Journal of Australasia, 7(1), 27-35. Retrieved September 6, 2011, from http://www.aes.asn.au/publications/ Vol7No1/Contribution_Analysis.pdf

Mainstreaming Good Practices in Basic Education. (2009). Annual school monitoring report 2008. Jakarta, Indonesia: UNICEF. 
Mayne, J. (1999). Addressing attribution through contribution analysis: Using performance measures sensibly. Discussion paper. Ottawa, Canada: Office of the Auditor General of Canada. Retrieved September 6, 2011, from http://dsp-psd.pwgsc. gc.ca/Collection/FA3-31-1999E.pdf

The Mitchell Group. (2008). The midterm evaluation of USAID/Indonesia's Decentralized Basic Education (DBE) project: Vol. 1, final report. Prepared under the USAID Advancing Basic Education (ABE-BE) Indefinite Quantity Contract, No. EDH-I-00-05-0035-00. Jakarta, Indonesia: USAID. Retrieved September 6, 2011, from http://indonesia.usaid.gov/documents/ document/Document/525/DBE_Evaluation_ Final_Evaluation_Report_3

RTI International. (2006). Annual progress monitoring report, September 2006, phase 1, 2 and 3 districts. Prepared under the USAID Managing Basic Education (MBE) project, Contract No. LAG-I-16-99-00009-00. Jakarta, Indonesia: USAID.

RTI International. (2007). Policy reform in education planning. Special report prepared under Decentralized Basic Education 1, Contract No. 497-M-00-05-00029-00. Jakarta, Indonesia: USAID. Retrieved September 6, 2011, from http:// pdf.usaid.gov/pdf_docs/PNADO409.pdf

RTI International. (2009). Study of the legal framework for the Indonesian basic education sector (2nd ed.). Report prepared under Decentralized Basic Education 1, Contract No. 497-M-00-05-00029-00. Jakarta, Indonesia: USAID. Retrieved September 6, 2011, from http:// pdf.usaid.gov/pdf_docs/PNADT232.pdf

RTI International. (2010). Implementing school-based management in Indonesia-The DBE1 experience 2005-2010; impact study. Report prepared under Decentralized Basic Education 1, Contract No. 497-M-00-05-00029-00. Jakarta, Indonesia: USAID. Retrieved September 2, 2011, from http:// pdf.usaid.gov/pdf_docs/pdacq711.pdf and from http://www.dbe-usaid.org, Resource Materials, Reports.
Teddlie, C., \& Tashakkori, A. (2009). Foundations of mixed methods research: Integrating quantitative and qualitative approaches in the social and behavioral sciences. Los Angeles: Sage Publications.

Umansky, I., \& Vegas, E. (2007). Inside decentralization: How three Central American school-based management reforms affect student learning through teacher incentives. World Bank Research Observer, 22(2), 197-215.

United States Agency for International Development (USAID). (2011). USAID evaluation policyEvaluation: Learning from experience. Washington, DC: USAID. Retrieved September 6, 2011, from http://www.usaid.gov/evaluation/ USAIDEvaluationPolicy.pdf

White, H. (2009). Some reflections on current debates in impact evaluation. Working Paper No. 1. New Delhi, India: International Initiative for Impact Evaluation (3ie). Retrieved September 6, 2011, from http://www.3ieimpact.org/admin/pdfs_ papers/3.pdf

World Bank. (2008a). What do we know about school-based management? Washington, DC: World Bank. Retrieved September 2, 2011, from http://siteresources.worldbank.org/ EDUCATION/Resources/2782001099079877269/547664-1099079934475/5476671145313948551/what_do_we_know_SBM.pdf

World Bank. (2008b). What is school-based management? Washington, DC: World Bank. Retrieved September 2, 2011, from http:// siteresources.worldbank.org/EDUCATION/ Resources/278200-1099079877269/ 547664-1099079934475/547667-1145313948551/ what_is_SBM.pdf

World Bank. (2010, December). Making BOS effective under decentralization. Jakarta, Indonesia: Human Development Sector, World Bank. Retrieved September 2, 2011, from http://ddp-ext. worldbank.org/EdStats/IDNbr10.pdf 

RTI International is an independent, nonprofit research organization dedicated to improving the human condition by turning knowledge into practice. RTI offers innovative research and technical solutions to governments and businesses worldwide in the areas of health and pharmaceuticals, education and training, surveys and statistics, advanced technology, international development, economic and social policy, energy and the environment, and laboratory and chemistry services.

The RTI Press complements traditional publication outlets by providing another way for RTI researchers to disseminate the knowledge they generate. This PDF document is offered as a public service of RTI International. 